\title{
Wordarrows: The performative power of language in N. Scott Momaday's non-fiction work
}

\author{
Anna M. Brígido-Corachán \\ anna.brigido@uv.es \\ IULMA - Universitat de València, Spain
}

\begin{abstract}
This article focuses on two non-fiction works by Native American author N. Scott Momaday: his 1969 historical memoir The Way to Rainy Mountain and his essay collection The Man Made of Words It specifically tackles performative conceptions of language in the Kiowa storytelling tradition, where words are experienced as speech acts that have the power to intervene in surrounding realities. Taking into account $20^{\text {th }}$ century ethno-cultural and linguistic policies in the United States, the article also reflects on the role indigenous languages may play in contemporary Native American Literature, which has most often been written in English.
\end{abstract}

Keywords: N. Scott Momaday, Kiowa, indigenous languages and cultures, history of the United States, Native American Literature

"We cannot exhaust the power of words; that power is intrinsic" N. Scott Momaday, The Man Made of Words

"A well-chosen word, like a well-made arrow, pierces the heart" Kenneth Lincoln, Native American Literary Renaissance

\section{INTRODUCTION}

This article explores Native American author N. Scott Momaday’s Kiowa-based theory of language and culture as sketched in his experimental historical piece The Way to Rainy Mountain and in some of his early essays ${ }^{1}$. Originally published in 1969, although based on an earlier text (his 1967 privately-printed edition entitled The Journey of Tai-Me), The Way to Rainy Mountain operates both as a history of the Kiowa people and as a familiar memoir filtered through personal reminiscences. It is considered, together with Momaday's Pulitzer prize-winning novel, House Made of Dawn (1968), one of the key inaugural texts of the Native American Renaissance - a

\footnotetext{
${ }^{1}$ Research for this article has been supported by the R+D project "La cultura como recurso de desarrollo. Prácticas, discursos y representaciones en procesos modernizadores contemporaneous”, financed by the Spanish Ministerio de Ciencia e Innovación.
} 
rich literary movement that brought public visibility and recognition to First Nations authors from a wide variety of Native and mixed heritages ${ }^{2}$.

Born in Lawton, Oklahoma, of Kiowa and Cherokee descent, Momaday spent his childhood and youth among the Tewa-speaking Native Pueblos of New Mexico, in the town of Jemez, where his father was a school principal. He continued to live in New Mexico during his college years and later in California, while completing his doctoral studies at Stanford University - always far from the Kiowa landscape he so vividly evokes in The Way to Rainy Mountain (WRM henceforth). As he explains in his autobiography The Names. A Memoir, Jemez Pueblo "was my home from the time I was twelve until I ventured out to seek my fortune in the world” (Momaday 1976: 11).

Mirroring his personal spatial dislocations, Momaday's WRM is symbolically divided into three thematic blocks having to do with movement: “The Setting Out”, “The Going On”, and "The Closing In”. These sections recall the nomadic journey of the Kiowa from their ancestral Northwestern territory through the Great Plains until they reached the upper Arkansas river region, where they finally settled before it became Indian Territory and then Oklahoma, a state of the new American nation ${ }^{3}$. Momaday's autobiographical journey within WRM also charts such a shift, imagining the author as he returns home to Rainy Mountain Creek to visit his grandmother's burial ground in the Kiowa reservation, where he spent significant periods of his early childhood ${ }^{4}$. This

\footnotetext{
${ }^{2}$ In 1968 the American Indian Movement (AIM) was founded in Minneapolis and a year later, as Native activists began the 20-month occupation of Alcatraz Island in protest for centuries of suppression of American Indian socio-political, territorial, cultural, and linguistic rights, Momaday's novel was awarded the Pulitzer Prize. Together with The Way to Rainy Mountain's coming to light, 1969 was also the year of publication of Custer Died for your Sins: An Indian Manifesto, a groundbreaking political and philosophical piece by Native American intellectual Vine Deloria. Fostered by such historical turning point, the first Native American Studies programs were launched at the University of California, Berkeley, and at the University of Minnesota at Twin Cities (Coulombe 2011:35). For a more detailed account of the origins of this literary movement and of Momaday's prominent position within it, see Kenneth Lincoln's 1983 Native American Renaissance and Jace Weaver's more recent "The mystery of language. N. Scott Momaday: An appreciation” (2008). Chad Allen (2005: 208) and Robert Warrior (2005: 154-6) further explore the links between Momaday's work and the late 1960s/early 1970s watershed context of Native American political and intellectual activism.

${ }^{3}$ The Kiowa reservation is currently located in southwestern Oklahoma, where the Kiowa had settled in the early nineteenth century. See Mooney (1979) and Kracht (2007) for further details.

${ }^{4}$ According to Edward Said, contemporary intellectual discourse is shifting from filiative to affiliative modes of relation. He describes filiation as "belong(ing) to the realms of nature and of 'life' whereas affiliation belongs exclusively to culture and society" (1983: 20). For a more detailed account of Momaday's af-filiative strategies in The Way to Rainy Mountain and in his longer memoir The Names see Brígido-Corachán (2011).
} 
memorial return of the author also builds a movement of af-filiation into tribal culture (Brígido-Corachán 2011: 114).

“The Setting Out”, the opening section after Momaday's preface and introduction, describes the mythical emergence of the Kiowa into this world from a hollow log as well as their acquisition of cultural and religious traits as they met other tribes on their nomadic eastward journey. “The Going On” then includes various historical episodes from the period when the Kiowa were one of the most important warrior, buffalohunting societies on the Great Plains. Lastly, “The Closing In” turns to the last years of the Kiowa as an independent tribe at the close of the $19^{\text {th }}$ century, prior to white dominance and reservation enclosure. These last historical reminiscences are based on direct eyewitness accounts preserved from family members and neighbors who lived through the experiences later to be translated by the author's Kiowa-speaking father, $\mathrm{Al}$ Momaday, a key figure in the chain of historical and linguistic transmission.

The work's three main sections are further divided into twenty-four short passages, which are visually and thematically organized in groups of three vignettes. Facing each other on the page, these vignettes weave creative interconnections between three dimensions: a mythical, a historical/ anthropological, and a familiar version of a story or reminiscence. These entwined dimensions are also reinforced, at times, by a fourth element, a series of drawings sketched by Momaday's father, Al. Momaday refers to these three juxtaposed textual discourses as voices whose narratives and personas move freely from the mythical to the personal or historical dimensions and vice versa, creating a "polyphonic version of Kiowa historiography that questions traditional divisions between fact and fiction, history and myth” (Brígido-Corachán 2011: 113-4). The first set of vignettes is organized around the idea of "coming out"; they describe the emergence of the Kiowa into the world and their symbolic first act of identityconstruction through language: the self-naming of the tribe. The origin of the name "Kwuda", which means "coming out", is explained in both the mythical (the oral tradition) and the historical vignettes. Both dimensions are complemented by Momaday's personal reminiscence, as he "came out upon the Great Plain in the late spring” (1969/2001: 17), an encounter with his childhood landscape that will trigger the remembering act that is The Way to Rainy Mountain. In this manner, Momaday's first set of reflections specifically links the concepts of emergence and birth with language, 
meaning and identity-making, as they are inscribed in the landscape and re-imagined through the linguistic act of memorial contemplation.

\section{LANGUAGE, PERFORMATIVITY AND THE ORAL TRADITION}

Symmetrically organized as a triptych between each facing page, The Way to Rainy Mountain lends equal weight to oral and written, visual, mythic, historical, and familiar sources as each is blended into a composite narrative form that is impossible to classify $^{5}$. Elaine A. Jahner has described Momaday's historical and personal segments as a kind of "commentary" on the oral tradition, of which he himself is the audience. In this manner, the narrative process of this work becomes an imitation of a performative event. According to Jahner, “The perception of oneself as a member of a mythteller's audience - a member who is discovering one's own context of vital meaning $(\ldots)$ - is basic to understanding Momaday’s role as the persona in his own work” (1983: 217). The Way to Rainy Mountain thus echoes the structural and aesthetic features that shape traditional Native storytelling and writing. They reproduce the oral story and also evoke what Daniel Mato denominates “extratextual acts” (1990: 16): an audience (as he dialogues with himself or listens to his grandmother's stories), a place (the homestead at Rainy Mountain Creek), a particular oral rhythm, and the conjuring up of voices from the past. The Way to Rainy Mountain recreates the performative aspects of the storytelling process within the text by summoning up its context of enunciation. According to Momaday, the writer and the storyteller are indivisible, as they are both “concerned to create himself and his audience in language” (in Coltelli 1990: 93). WRM thus functions as an act of creation where two types of reader, indigenous and nonNative, are invoked in different manners. Those readers not acquainted with Kiowa culture will necessarily have to learn how best to listen to the stories it tells; they will be given an entryway into Kiowa history which they will complement by contributing connections of their own to the triptych of loosely intertwined reminiscences. Drawing their own signifying trajectories, all Native and non-Native readers thus participate in the remembering process, generating varying reflections and responses while traveling

\footnotetext{
5 It is interesting to point out that this triptych division was introduced by the book designer Bruce Gentry, as the original voices in Momaday's manuscript were actually consecutive. See Interview with Kay Bonetti, in Roemer (1988: 3).
} 
to Rainy Mountain as well as to their own familiar landscapes. As Momaday expresses in the preface to his essay collection The Man Made of Words, the storyteller

creates the storytelling experience and himself and his audience in the process (...). The storyteller creates himself in the sense that the mask he wears for the sake of telling the story is of his own making, and it is never the same. He creates the listener in the sense that he determines the listener's existence within, and in relation to, the story, and it is never the same (...) And this imagining is the burden of the story, and indeed it is the story. (1997: 3)

Like the storyteller shaping his listener in the telling, Momaday develops a sort of cartographic language in WRM. A map is laid out for the reader to follow, with the preface and the introduction serving as a guide through the various Kiowa scenes. The two framing poems, "Headwaters” and "Rainy Mountain Cemetery”, give us a symbolic beginning and a poetic textual end. His textual format is thus not expansive and never explicitly ambitious, but rather intimate and inclusive of all voices. Meaning is ultimately created out of the active recombination and weaving of passages in the reader's mind, as such parallel structures encourage free association and the connection of ideas. Adding to this effect, Momaday's particular “storytelling experience” is characterized by the economy of his use of the English language, which, reduced to its bare essence, makes every word echo within countless subtexts ${ }^{6}$. In his essay "The Native Voice in American Literature”, the Kiowa author explains that

\begin{abstract}
in the oral tradition one stands in a different relation to language. Words are rare and therefore dear. They are jealously preserved in the ear and in the mind. Words are spoken with great care, and they are heard. They matter and they must not be taken for granted; they must be taken seriously and they must be remembered (...) Words are intrinsically powerful. They are magical. By means of words can one bring about physical change in the universe. (1997: 15-6)
\end{abstract}

Most cultures embrace, in one way or another, the performative function of language. Many Native cultures, additionally, believe that storytelling is performative, that is, in the telling of a story the events it describes may materialize and happen ${ }^{7}$. The Kiowa respect the power of words that, as speech acts, may have an immediate or belated effect in the real world surrounding us. Momaday lyrically conveys this idea in section VIII of WRM, where he includes three reminiscences, one in each of the dimensions, all

\footnotetext{
${ }^{6}$ Together with his strong Kiowa storytelling roots, which he primarily inherited from his father and Kiowa grandparents, Momaday's prose is also permeated by Western poetic discourse. His doctoral dissertation focused on the poetry of Frederick Goddard Tuckerman (1963) and his mentor at Stanford University was the poet Yvor Winters. Moreover, his transculturated language philosophy is clearly inspired by the idealist approach of Wallace Stevens. Momaday, in fact, borrows the title of his book collection from a poetic line by Stevens: "men made out of words" (See Schubnell 1985: 45-6).

${ }^{7}$ See, for example, the power of Laguna Pueblo stories in Leslie Silko's novel Ceremony (1977), where the narrative and performative modes blend into one another (Hoilman 1979: 65).
} 
illustrating the tangible effects of words in action. In one of the mythic tales about the sacred Kiowa Twins, he narrates how the intrepid children are able to escape a murderous giant who tries to suffocate them with smoke by chanting the magic Kiowa word thain-mom (“above my eyes”) - a word that had been given to them by grandmother spider to confront evil and danger (WRM 1969/2001: 32) ${ }^{8}$. This story from the mythical dimension is paired with a familiar anecdote about Momaday's own grandmother, Aho, who also had a powerful word, zei-dl-bei ("frightful”), which she would say out loud when facing a difficult or harmful situation. As the author explains: “(I)t was not an exclamation so much, I think, as it was a warding off, an exertion of language upon ignorance and disorder” (WRM 1969/2001: 33).

Finally, in the historical commentary, Momaday describes the solemn Kiowa protocols that were linguistically displayed when referring to a dead person. Because words have the potential to release certain sacred energies, the Kiowa would avoid using the names of their dead, and would go as far as substituting them (often also quotidian referents) with new terms, while the old words became taboo for a whole generation and were thus forgotten. In a similar way, many words would leave the Kiowa world along with the people that symbolically owned them, to be later substituted by new ones ${ }^{9}$.

A word has power in and of itself. It comes from nothing into sound and meaning; it gives origin to all things. By means of words can a man deal with the world on equal terms. A man's name is his own; he can keep it or give it away as he likes (...). The dead take their names with them out of the world. (WRM 1969/2001: 33)

Despite this continually transforming dynamism and the creative energies associated with the Kiowa language, it continues to be endangered, together with the remaining 200 indigenous languages that are still spoken in the United States. Native American languages are rich repositories of history, cultural knowledge and spiritual beliefs, yet endless socio-cultural impositions by the dominant society, compounded by decades of boarding school internment and urban relocation for Native American youth, away from

\footnotetext{
${ }^{8}$ In the Kiowa mythology, the Twin Brothers, sons of the Sun, are considered to be two halves of the same son - his only child. Maurice Boyd actually refers to them as "half-boys", which is more precise than the term twins. See Berner (1988: 60), Note 1.

9 See Mooney's classic anthropological account (1979:152) and Momaday's own explanation in the historical fragment of section VIII, page 33, in The Way to Rainy Mountain.
} 
their families, have eroded linguistic practice in Native households ${ }^{10}$. According to Gus Palmer Jr., Kiowa-speaking suffered a tremendous decline throughout the $20^{\text {th }}$ century, and today only about 100 fluent speakers, most of whom are over 70 years old, can be found among the 11,000 registered tribal members, (2007: 16). In his preface to The Man Made of Words, Momaday explains that, as a very young child, he heard both English and Kiowa words at their homestead in Rainy Mountain Creek, although his father and mother (of Kiowa and Cherokee heritage respectively) used English as the common family language ${ }^{11}$.

From the time I was born my parents spoke to me in English, for that was my mother's Native tongue, and she could speak no other (...). The house and the arbor of the homestead on Rainy Mountain Creek in Oklahoma crackled and rang with Kiowa words, exclamations, and songs that even now I keep in my ear. But I would learn only a part of the whole, and I would never learn to converse easily in Kiowa. (...) My Kiowa family spoke to me in broken English, or their Kiowa words were translated into English for me by my father. Now when I hear Kiowa spoken - mostly by the older people who are passing away - it is very good. The meaning most often escapes me, but the sound is like a warm wind that arises from my childhood. It is the music of memory. (1997: 7. My emphasis)

For Native American authors using English as their primary vehicle of expression (in the great majority of cases, such as Momaday's, because it is their mother tongue), Native words in a text may indeed function as a "music of memory" accompanying the text (1997:7). And while this expression may sound nostalgic, we must remember that it is not the Native endangered language itself that is romanticized here, but Momaday's childhood, his linguistic self-discovery in the company of loved ones, that is lyrically evoked. Perhaps even more poignantly, these isolated words in the Kiowa language that Momaday is able to use, and even those he does not dare use for lack of fluency, become a powerful historical reminder that points to the legacy of linguistic impositions and colonial abuses still dominating white/Native relations in the continent ${ }^{12}$. And that a

\footnotetext{
${ }^{10}$ According to Johansen, approximately 200 indigenous languages are currently spoken in the USA, although only 20 of them continue to be taught at home as a first language (Praeger Handbook 5, qtd by Coulombe 2011: 29).

${ }^{11}$ Between the age of 12 and 18 Momaday grew up surrounded by Jemez-speaking families, among the Pueblo of New Mexico. He actually used his knowledge of Navajo culture to contextualize his celebrated novel House Made of Dawn.

${ }^{12}$ Most contemporary Native writers in the United States are university-educated, mixed-blood authors writing in English, with very little command of the languages spoken by their ancestors, although there are a few exceptions primarily in the poetic field. Simon Ortiz and Ray Young Bear, for example, often use Native words from their mother tongues (Keresan and Mesquakie, respectively) in their poetic compositions, but generally write in English. This situation (the full presence of Native languages as literary vehicles) is quite different in the case of Latin American indigenous writers who are, for the most part, Native speakers of endangered indigenous languages, and publish their work in bilingual texts, although, unlike their US counterparts, the dissemination of these texts is rather limited.
} 
historical and literary piece as moving as WRM could be built from what pieces remain, in the “enemy’s language”, may be Momaday's most powerful statement of all ${ }^{13}$.

\section{THE ARROWMAKER AND THE POWER OF LANGUAGE}

The Way to Rainy Mountain moves the reader not merely because of its original structure or because of the effective combination of the four intertwined dimensions (mythic, historical, personal, and visual) but through its contagious forward motion the intimate yet powerful, performative wordarrows (Vizenor 2003) ${ }^{14}$ that, although using the English language as a vehicle, open up a new historical space for the Kiowas in the local/national imagination. For, in WRM there are many simultaneous approaches, “many landmarks, many journeys in the one” (WRM 1969/2001: 4). Momaday points out that there are many ways to organize all these memories and knowledges; and although his is just "one way in which these traditions are conceived, developed, and interfused in the human mind" (ibid) it is one rooted in Kiowa historiography and worldviews. Moreover, by using the English language as a tool, Momaday is actually engaging in an act of “anti-imperial translation” (Krupat 1996: 30) - an action that neutralizes the violence engrained within the first acts of translation that took place between Natives and Western colonizers, a vindicative action that, borrowing the words of Arnold Krupat, “conceptualiz(es) the tensions and differences between contemporary Native American fiction and 'the imperial center'” (ibid). Even if traditional oral stories are recalled using a language that is foreign to them, they are being rescued from the official national archive and reconfigured to suit the purposes of a contemporary Kiowa storyteller bringing to the fore the history of his people. Furthermore, this restored history is also built on direct eyewitness accounts and traditional narratives from his community, many of which were originally shared with the Momadays by relatives and neighbors in the Kiowa language. Part and parcel of all Native American writers' modern heritage, English also functions as a lingua franca that may disseminate the

\footnotetext{
${ }^{13}$ I borrow the expression from Joy Harjo's well-known anthology Reinventing the Enemy's Language: Contemporary Native Women's Writings of North America (1997).

14 Gerald Vizenor's critical term, based on Momaday's story, “The Arrowmaker”, which I discuss later in this article. See Vizenor's Wordarrows: Native States of Literary Sovereignty for a more detailed explanation.
} 
message as widely as possible, among other Native communities and non-Native readers.

Some scholars have accused Momaday of relying excessively on modernist structures, nostalgia and for having an apolitical stance (Forbes 1987, Krupat 1989). The Way to Rainy Mountain indeed seems to nostalgically invoke a time that is gone but which pervades the oral stories even in their written reconfiguration. The power held and transmitted through these stories is, however, not mystified and is very much alive in the text. This power derives from the vitality and deep creativity of language in its “original state”, a state associated by Momaday with the oral tradition (Momaday 2007). Orality has always been central to Kiowa historicity even in scriptural accounts, as the keepers of their historical calendars, which were picto-ideographic, always accompanied their visual elements with an explanatory oral account (Mooney 1979). In $W R M$, these oral memorial narratives are again re-activated by Momaday's "transfiguring tongue" ${ }^{15}$. The Kiowa language itself, a language in which the author cannot easily converse and that he describes as the "music of memory" (1997: 7), may at times acquire romanticized undertones but it certainly has a key empowering role in the narrative. The performative words chanted by his grandmother, Aho, contribute to build a historical mood that is grounded on Kiowa ways of conceptualizing language and of narrating history. They also act, as we have already mentioned, as a reminder of the colonial legacy of linguistic destitution still ongoing in the Americas.

The performative power of language is perhaps best explained in Momaday's seminal essay “The Man Made of Words”, which was first written as a keynote lecture at the First Convocation of American Indian Scholars in March 1970, at Princeton University, and was later republished in his essay collection of the same title. According to Momaday "much of the power and magic and beauty of words consist not in meaning but in sound. Storytellers, actors, and children know this, too" (1997: 7). He later contradicts himself and demonstrates that the power of words lies not merely in their sound, but also in their meaning and in their recollection, as his famous tale of the arrowmaker illustrates. In this traditional oral story (the first tale Momaday ever heard

\footnotetext{
${ }^{15}$ In his famous poem "Robinson Crusoe", Caribbean poet Derek Walcott refers to the transfigurative power of the English language to describe new world realities when used by the American Native in a transculturated, anti-imperialistic manner. The Native is epitomized, in the poem, by Daniel Defoe's foundational character, Friday. See Walcott's Collected Poems 1948-1984 (1986: 68).
} 
as a child), as the arrowmaker is straightening an arrow with his teeth inside his teepee, he is able to identify and kill his hidden enemy, who is lurking in the shadows outside. It is the enemy's ignorance of the Kiowa language that prevents him from understanding the arrowmaker's warning (1997: 9-12):

"I know that you are there on the outside, for I can feel your eyes upon me. If you are a Kiowa, you will understand what I am saying, and you will speak your name”. But there was no answer, and the man went on in the same way, pointing the arrow all around. At last his aim fell upon the place where his enemy stood, and he let go of the string. The arrow went straight to the enemy's heart. $(1997: 10)^{16}$

Speaking and understanding the Kiowa language work here as a symbol of recognition of one's own clan as well as a weapon to challenge one's enemy. The arrowmaker's pronouncement “is also a question and a plea” (Momaday 1997: 11), and an acknowledgement of Kiowa identity through language. The "arrowmaker ventures to speak because he must: language is the repository of his whole knowledge and experience, and it represents the only chance he has for survival” (ibid). Intellectual resourcefulness and survival are encoded in the arrowmaker's words, just as his teeth have left an oral imprint in his story-arrow. As Momaday explains: "The point of the story lies not so much in what the arrowmaker does, but in what he says - and, indeed, that he says it. The principal fact is that he speaks, and in so doing, he places his very life in the balance” (1997: 10). Momaday’s arrowmaker thus establishes an intrinsic connection between language and literature and he is, as Robert Warrior points out, "a necessary stopping place in situating (Momaday’s) relationship to language, literature, and the natural world” (2005: 171).

Many Kiowa of Momaday's generation have lost that ability to speak their ancestors' language but, still imbued in tribal culture, they have not forgotten the story which continues to be revitalized by other means. The Way to Rainy Mountain's thorough recovery of oral history is lyrically mobilized through Momaday's English-shaped transfiguring wordarrows, and these evince a strong commitment to tribal heritage. Momaday is, above all, a cross-cultural American and as such he can effectively integrate Kiowa historiography with a textual literary template, product of his academic education and Western influences. Thus, although orality is fundamental to the recovery

\footnotetext{
${ }^{16}$ This story also appears as one of the mythical narratives in section XIII of The Way to Rainy Mountain (1969/2001: 46).
} 
of Kiowa cultural and intellectual traditions, it is not, by any means, the only one. There are many ways to Rainy Mountain within WRM, and any further textual, physical or linguistic resource that may enable Kiowa heirs to reclaim tribal territories and autochthonous historical and intellectual traditions should be embraced and celebrated.

\section{CONCLUSION}

"language, that miracle of symbols and sounds that enable us to think, and therefore to define ourselves as human beings” (Momaday 1997: 1)

If, as Momaday suggests, language and thought are intrinsically intertwined, if "(l)anguage is a creator of reality" ${ }^{17}$, how does his not speaking Kiowa, except for a handful of words, influence his worldview? As we have seen in this article, one may be tempted to think that the author fetishizes the oral tradition by setting it at the core of a memorial imagination that is nostalgic and artificial in nature, since it is expressed through the "enemy's language". However, his use of the colonial language as a vehicle serving Kiowa expression is the result of centuries of imperialistic impositions and linguistic aggression. Momaday's masterful use of English is able to challenge this legacy. As Jace Weaver points out, "Momaday is obsessed with words - their tone, their sonorousness, their rhythm, how they feel in the mouth” (2008: 81). In his works, he is clearly influenced by familiar linguistic rhythms passed on to him, together with the stories, by his Kiowa-speaking father. Momaday additionally bends English words at will so they may fit his own authorial designs: the making of a historical Kiowascape where the absence of the Kiowa language (the sacred names that each dead Kiowa took along to the other world) actually fills the empty spaces of each page, as his people are remembered and honored. Momaday's own personal memoir, The Names, further strengthens the memorial process by giving flesh and visual protagonism to each of his forefathers and foremothers speaking in The Way to Rainy Mountain, whose names and stories thus continue to endure on the page.

Wordarrows, in any language, can serve as imaginative weapons to organize and channel one's anger and creative energies, to carve one's place in the world. Through

\footnotetext{
17 “The Mystery of Language: Native American Oral Tradition” Charter Lecture delivered at the University of Georgia, Athens, October 20, 1994. Quoted by Jace Weaver (2008: 81).
} 
words, Native authors can re-construct, activate, and protect textual, familiar, and cultural territories from the socio-economic plundering and intellectual dispossession they have withstood for centuries. Imagination “enables us to use language to its highest potential. It enables us to realize a reality beyond the ordinary, it enables us to create and to re-create ourselves in story and literature. It is the possible accomplishment of immortality" (Momaday 1997: 2). With the help of his Kiowa-speaking and memorykeeping family, Momaday, the arrowmaker, is able to decode his Native legacy and to render it in a language that, even if not fully Kiowa in appearance, proves to be an effective, moving, and empowering vehicle for the present cross-cultural generation in charge of projecting their tribal traditions into the future.

\section{REFERENCES}

Allen, C. 2005. “N. Scott Momaday: Becoming the bear”. In Porter, J. and K.M. Roemer (Ed.) The Cambridge Companion to Native American Literature. Cambridge: Cambridge University Press, 207-220.

Berner, R.L. 1988. “The Way to Rainy Mountain: Structure and language” In. Roemer, K.M. (Ed) Approaches to Teaching Momaday's The Way to Rainy Mountain. New York: MLA, 54-61.

Brígido-Corachán, A.M. 2011. "Native journeys of self-figuration: N. Scott Momaday's The Way to Rainy Mountain and Gloria Anzaldúa's Borderlands/La Frontera”. In Simal, B. (Ed.) Selves in Dialogue. Intra-Inter Ethnic Study of Self-life Writing. Amsterdam: Rodopi, 109-133.

Coltelli, L. 1990. Winged Words: American Indian Writers Speak. Lincoln: University of Nebraska Press.

Coulombe, J.L. 2011. Reading Native American Literature. New York: Routledge.

Forbes, J. 1987. “Colonialism and Native American literature. Analysis”. Wicazo Sa Review 3, 17-23.

Harjo, J. (Ed.) 1997. Reinventing the Enemy's Language: Contemporary Women's Writings of North America. New York: Norton and Company. 
Hoilman, D.R. 1979. “'A world made of stories”: An interpretation of Leslie Silko’s Ceremony”. South Dakota Review 17, 4.

Jahner, E. 1983. “A critical approach to American Indian literature”. In Allen, P.G. (Ed.) Studies in American Indian Literature. New York: MLA, 211-224.

Kracht, B.R. 2007. “Kiowa”. In Encyclopedia of Oklahoma History and Culture. Oklahoma Historical Society. 15 January $2012<\underline{\text { http://digital.library.okstate.edu/ }}$ entries/K/KI017.html>

Krupat, A. 1989. The Voice in the Margin: Native American Literature and the Canon. Berkeley: University of California Press.

Krupat, A. 1996. The Turn to the Native: Studies in Criticism and Culture. Lincoln: University of Nebraska Press.

Lincoln, K. 1983. Native American Renaissance. Berkeley and Los Angeles: University of California Press.

Momaday, N.S. 1969/2001. The Way to Rainy Mountain. Albuquerque, NM: University of New Mexico Press.

Momaday, N.S. 1976. The Names: A Memoir. New York: Harper and Row.

Momaday, N.S. 1997. The Man Made of Words: Essays, Stories, Passages. New York: St. Martin’s Press.

Momaday, N.S. 2007. "When dogs could talk. Among words in a state of grace”. World Literature Today 18 (5), 15-17.

Mooney, J. 1979. Calendar History of the Kiowa Indians. Washington, D.C.: Smithsonian Institution Press.

Palmer Jr., G. 2007. “Kiowa”. World Literature Today 81 (5), 16.

Roemer, K.M. (Ed.) 1988. Approaches to Teaching Momaday's The Way to Rainy Mountain. New York: MLA.

Said, E.W. 1983. The World, the Text and the Critic. Cambridge, MA: Harvard University Press. 
Schubnell, M. 1985. N. Scott Momaday: The Cultural and Literary Background. Norman: University of Oklahoma Press.

Vizenor, G. 2003. Wordarrows: Native States of Literary Sovereignty. University of Nebraska Press.

Walcott, D. 1986. Collected Poems 1948-1984. New York: Farrar, Straus and Giroux.

Warrior, R. 2005. The People and the Word. Minneapolis: University of Minnesota Press.

Weaver, J. 2008. “The mystery of language: N. Scott Momaday, an appreciation”. Studies in American Indian Literatures 20 (4), 76-87.

Received: 19 September 2011

Accepted: 07 October 2012

Cite this article as:

Brígido-Corachán, A.M. 2012. "Wordarrows: The performative power of language in N. Scott Momaday’s non-fiction work”. Language Value 4 (2), 56-69. Jaume I University ePress: Castelló, Spain. http://www.e-revistes.uji.es/languagevalue. DOI: http://dx.doi.org/10.6035/LanguageV.2012.4.2.5

ISSN 1989-7103

Articles are copyrighted by their respective authors 